\title{
Contending Perspectives on Development: A Critical Appraisal
}

\author{
Muhammad Tasiu Dansabo
}

\author{
Department Of Sociology \\ Usmanu Danfodiyo University, \\ Sokoto-Nigeria
}

\section{Doi:10.5901/mjss.2013.v4n16p41}

\begin{abstract}
There is no doubt that various scholarly studies were carried out on Development in Nigeria; there are still gaps to be filled. This is due to the fact that scholars tend to generally concentrate on the study of aspects of Development and the history of poverty in Nigeria. The paper therefore provided in sight on the gaps left on touched by scholars with a view to proffering space for this work in previous works. Specifically, the paper seeks to give a critical appraisal of theories of development with particular reference to Nigeria. To achieve this, the paper is divided into sections on introduction/ conceptual clarification of the key concept (development), highlights on the types of development. Discussion in this section leads to the spine of the paper which is a critical appraisal of development theories where theories such as (the Functionalist, Marxist, Modernization, Dependency and World system) were critically appraised. The paper is premised on the three fundamental questions asked by Seer in an attempt to assess the level of development of a nation. The questions are: what happened to poverty, what happened to unemployment, what happened to inequality? If these variables are on the decline from high level, then beyond doubt there has been a period of development of the country concerned. But if one or two of these central indicators are going worse, it will be strange to call the result as development even if the national income has developed like in the case of Nigeria. Considering the level of poverty and unemployment and the wide gap between the rich and the poor, one can argue that this assertion is very relevant in an attempt to establish a link between these problems and the level of development in the country. The final section of the paper draw conclusion where attempt was made at suggesting two perspectives as framework for analyzing the developmental plight of Nigeria.
\end{abstract}

Keywords: Development, Theories, Nigeria, Appraisal, Poverty, Unemployment, Inequality

\section{Introduction}

Development has been defined variously. The economists and administrators are, of course explicit, defining development in terms of increases in elaborate quantitative indices of national product, income, consumptions, etc., though there are, sometimes contradictory definitions. Pitt (1976:32) uses development in the very general sense of the perceived increased effectiveness of social and economic activities and functions of the society or situation and in the range of options open to people. Ultimately, Pitt sees development as the perceived improvement in the quality of life, even when this means fewer goods and services. According to Walter Rodney, development is a many- sided process in human society. At the individual level, it means increased skill and capacity, greater freedom, self-discipline etc. At the societal level, development encompasses an overall approach in which a particular society has become capable of realizing its potentials in several spheres of life-political, economic, social etc.

Historically, the meaning of development or development of society was equated to economic growth. Adam Smith in his classical economic theory developed the idea that for a society to develop it needs first, economic growth i.e economic growth is equal to development. The classical theorists believe that development will come about naturally if there is increase in income, production of goods, services and 
wealth. (Dansabo, 2006:73).

Development on the other hand is multi-dimensional (Seers, 1973:82). Seers accepts the economic meaning to be central having radical implications on the political, social and cultural aspects. This implies that development may be equated to economic growth provided that the latter leads to the combating of social and political problems. In his article 'The meaning of development' he identified three fundamental questions to be asked about development of a country. These are what happened to poverty, what happened to unemployment, what happened to inequality? If these variables are on the decline from high level, then beyond doubt there has been a period of development of the country concerned. But if one or two of these central indicators are going worse, it will be strange to call the result as development even if the national income has developed like in the case of Nigeria. Considering the level of poverty and unemployment and the wide gap between the rich and the poor, one can argue that this assertion is very relevant in an attempt to establish a link between these problems and the level of development in the country.

\section{Types of Development}

There are many types of development such as economic development, social development, political development, cultural development and administrative development. But for the purpose of this paper economic and social development shall be considered.

According to Jary, J 2000:173 Collins internet linked dictionary of sociology, social and economic development has to do with any change which results in increased economic productivity and prosperity, and new and more complex forms of social structure and organization. The study of such development was a central concern of classic sociological theory. Economic and social development is usually used to refer to the specific process of industrialization in both its socialist and capitalist forms.

Social development should be seen in conjunction with cultural development. Social development is a reflection of the quality of life of individuals and groups in a society and the way they perceive and interpret the world around them. It could also be understood by reference to the existence and access to the ordinary man of certain basic facilities which enhance his/her wellbeing. The availability of these physical facilities should also enable the enhancement of psychological wellbeing of the people.

There are thus some indicators of social development as follows:

1. Improved education: This refer to the ability of an individual to read and write and the acquisition of skills as well as the general enlightenment by many members of the society. Education leads to the improvement in the quality of manpower and productivity of the society. Education is also the engine of technological advancement; its advancements also has implications on all aspects of life of the society. According to Oghuvbu (2007:27) development may be difficult in poor countries without qualitative and quantitative education. He further argued that" it may be difficult for a country to achieve economic development through education, if a high percentage of the population is living below or at poverty levels with series of hygienic problems". Commenting on the educational situation in Nigeria, Amzat (2009:159) argued that "the problem of education in Nigeria could... be traced to lack of proper public investment in education".

2. Improved health care delivery: This is also an important indicator of social development. Health care delivery is brought about by the provision of curative and preventive services. The effect of which is a fall in infant mortality, increase life expectancy of the people and an increase in the productivity of the labour force. It is said that health is wealth.

3. Provision of adequate housing facilities: This reflects the standard of living and the general condition of the society. No society can be regarded as developed when majority of its people sleep under bridges, market squares, patched and thatched houses.

4. Provision of adequate infrastructural facilities: This includes water, energy, good transport system and communication network necessary for modernization. 
5. Increase urbanization: Historically, there is correlation between social development on the one hand and the level of urbanization on the other hand. A higher urbanized society is easily amenable for development action. It means that urbanization is both a reflection and a stimulus to development.

6. Structural transformation: As a society develops, the basic social units of that society undergo definite changes bringing about structural changes.

7. Increase in social mobility: This means the physical movement of people from one geographical area to another for different reasons but usually for socio-economic and political reasons. It also refers to the ability of members of a society to achieve higher social standard on the basis of their abilities and achievement.

8. Cultural change: When there is socio-cultural development the values and beliefs of society undergo drastic change; language as a mechanism of communication becomes more functional and changes on things such as arts, literature, music, mode of dressing, sports and other forms of entertainment. The availability and access to the facilities to the ordinary citizen implies that his wellbeing is enhanced materially or physically.

On the whole a society is said to be socially develop if it is able to achieve environment in which the material as well as the psychological forms serve to improve social efficiency e.g people get to work on time, emergencies in the hospitals get prompt attention; the educational system turn out highly skilled and motivated individuals, even the attitude to work change for better.

Economic development on the other hand has to do with the establishment of an economic system capable by itself to raise and maintain production and the income levels of all groups in the society. The standard measurement of economic development in the capitalist countries is increased in national income or GNP measured periodically, usually annually. However, increase in production and income level should not be automatically equated with development unless such an increase leads to the improvement of standard of living of all segments of the population and the solution of socio-economic problems of the society.

When analyzing the concept of economic development, a distinction should be made between it and economic growth. Economic growth refers to quantitative improvement or increase of resources or wealth of society over time. Such increase may be brought about by introduction of new technology, discovery of new resources, and good harvest from favorable weather condition from predominantly agricultural society. Each of these may result to increase in production or income. Economic development as far as it concerns increase in production of goods and services can only be achieved if there is high degree of organization based on a far reaching division of labour. The process of economic development requires qualitative change in the structure of the economy without which internally generated growth cannot be sustained over time. Other elements of economic development include:

a. High level of employment.

b. Low level of inflation.

c. Improve infrastructural facilities such as transport, communication network, water supply and energy.

d. Low level of poverty.

Development therefore, when used in the context of this paper refers to the process of utilizing both human and material resources for the benefit of generality.

\section{An Appraisal of Development theories}

Development theory is a conglomeration of theories about how change in society is best to be achieved. Such theories draw on a variety of social scientific disciplines and approaches. There are several theories of development. Most theories about development emphasize the external influence whether beneficial (as in development propaganda) or exploitary (as in Marxist explanations) (Pitt, 1976). 


\subsection{The Functionalist Perspective}

The Functionalist examines structure and institutions in the society (Mohammed, n.d). The French sociologist Emile Durkheim develops the concept of functionalism which stresses the interdependence of the institutions of society and their interaction in maintaining cultural and social unity. His famous work is "The Division of Labour in Society" which describes how social order was to be maintained in a society and how primitive societies might make the transition to more economically advanced industrial societies. Durkheim suggested that in a capitalist society, with a complex division of labour, economic regulation would be needed to maintain order. He stressed that the major from a primitive social order to a more advanced industrial society could otherwise bring crisis and disorder. Durkheim further developed the idea of social evolution, which indicates how societies and cultures develop over time, much like a living organism, essentially saying that social evolution is like biological evolution with reference to the development of its components. Like organisms, societies progress through several stages generally starting at a simplistic level and then developing into a more complex level. Societies adapt to their surrounding environments, but they interact with other societies which further contribute to their progress and development (Wikipedia, free encyclopedia).

There are important differences between functionalists authors, the main tenets of the structural functionalist theory are:

a. Modern society is contrasted with traditional society which is seen as hindering economic development;

b. Change occurs through evolutionary stages which are broadly similar for all societies;

c. Third World countries need agents of change to help them break out of tradition;

d. Such agents of change may either come from within the society, such as modernizing elites, or may come from outside, for example with the injection of capital or education models;

e. Dual economies and dual societies may exist in contemporary $3^{\text {rd }}$ world countries. Some regions persist in traditional forms, whilst others, especially urban areas, experience modernization;

f. Both preferred and likely outcome are societies similar to those in Western Europe and the US.

It is obvious from the above that the functionalists' view of development could be likened to the postulations of the Modernization theory. The argument here is that the primitive societies are expected to copy and follow the path of advanced industrial societies. This pattern of relationship as will be seen in a later part of the review has detrimental negative effects to the traditional or underdeveloped societies.

\subsection{The Marxist Perspective}

The Marxist theory is based on materialism. The school of thought has been described as idealistic and normative in nature. The thrust of the theory is that society is held together by power and coercion for the benefit of those in power. The perspective outlines the development of society into stages; from feudalistic stage, agrarian economy, capitalism, socialism and finally communism.

- Feudalism: Under this stage the basic feature of society was such that society lives in the stage of nature-dependent heavily on what natural environment provide for necessities of life. It is also characterized by land ownership i.e feudal lords and slaves. It has no pronounced political institution and there was no money economy. Basically under this system the preoccupation of man was hunting and gathering. The Marxist belief that from the onset society was not form based on inequality but because of the nature of man and greed in him and the desire to accumulate wealth brought about the inequality and exploitation within the system and that with time this two classes will be in conflict between one another for control over the only means of production which is land.

- Agrarian Economy: This stage was not in the ideal Marxist theory but the hand work of neo-Marxist which provide us with a clear picture of the position of some developed countries that have not 
attain or witness the capitalist level of economic essentiality. The agrarian economic stage is a bridge between the feudal system and the capitalist system. It explains the position which most third world countries belong. The features of an agrarian economy is as follows:

i. $80 \%$ of the economy is agriculture while $20 \%$ accounted for modern economy.

ii. Since $20 \%$ accounted for modern economy, it means that there is some level of industrialization.

iii. The agrarian economy has also witness the introduction of modern currency of exchange and trade is also introduced.

iv. That modern technology has taken over from traditional method which was in existence in the feudal system.

- Capitalism: Capitalism is an economic system where private ownership and control of the means of production is the general rule. The guiding principle of the capitalist system is profit motive. The prices of commodities are settled by the forces of demand and supply. For this reason, the capitalist system has been accused of being survival of the fittest i.e those who have can acquire more while the have not becomes object of exploitation. Marx views capitalism as a system of exploitation. This situation gave rise to the emergence of three classes:

The capitalist or the bourgeoisie class.

- The working or the proletariat class.

- The peasantry class. This class is in intensive struggle and that this class struggle was a necessary condition for the birth of new social order called socialism.

Generally speaking capitalism has been developed in international system as result of the quest by the western countries to develop economically through political and economic exploitation of the weaker nations. The result of this process gave rise to the development of colonialism, which is a system that gave the European nations opportunity to conquer and exploit the material resources of the third world countries. Furthermore, in order for capitalism to survive, the concept of imperialism was used which is basically the economic domination and exploitation of other nations. In summary, capitalism is a system of gross inequality of exploitation and domination. It is also a system characterized by class struggle. The capitalist system was doom for failure; in the Marxist sense, capitalism is a necessary antithesis to the development of socialism.

\subsection{Modernization theory}

Modernization theory is a theory of development which states that development can be achieved through following the processes of development that were used by currently developed countries. Scholars such as Walt Rostow and A.FK Organski postulated stages of development applying to every country (Wikipedia, the free encyclopedia). Samuel Huntington considered development to be a linear process which every country must go through. One key factor in modernization theory is the belief that development requires the developed countries to aid developing countries to learn from their own progress.

In classical sociological theory, modernization was conceptualized by Durkheim as involving a process of social differentiation, by Weber as process of rationalization and by Marx as a process of commodification (Jary and Jary 2000:396).

There are various theories of underdevelopment in backward economies as given by the modernization theorists and this includes the following:

\subsubsection{Vicious circle of poverty theory}

This theory of poverty is one of the numerous theories advanced or put forward by the modernization school of thought to explain the backwardness of the less developing economies. It has been widely used to explain growth and development. The theory believes that the less developed countries have failed to develop 
because they are engulfed in web of vicious circle of poverty and stagnation. The central thrust of the theory is that the poor nations are underdeveloped because they are poor and they produce poor generations and that poverty means low income which generates low savings which in turn leads to low investment. The theory laid emphasis on the role of saving as an important variable in development. It also demonstrates that low saving is not only a cause but also an effect of initial poverty. Another explanation for the underdeveloped nature of poor nations is derived from the fact that existing low income are unable to provide the necessary required nutritional needs of the people. This in turn impairs the people's physical efficiency which reduces their productivity and this further perpetuates the low income which is the initial cause of poverty. The brains behind this theory are of the belief that to break the vicious circle of poverty, there has to be injection of massive capital investment from abroad. According to them a mass injection of capital from abroad will raise productivity and income which will in turn generate high savings and this high savings generated will sustain capital formation; this will in turn create profitable investment opportunities which will accelerate productivity and in turn higher income.

\subsubsection{Critique of viscous circle of poverty theory}

The theory is agreed to have thrown light to the shortages of capital and savings in the less developing countries but savings alone cannot propel or accelerate development. It is not true that the less developed countries do not save rather; there is no incentive to save and no opportunities to re-invest saved income. Finally, the theory is criticized seriously on the ground that it did not incorporate the foreign sector to act as a medium to alleviate the shortage of capital in less developed countries. The recommendation that massive injection of capital from abroad is not acceptable explanation to the development of these backward nations due to the activities foreign firms and multi-national corporations within these economies which continue to transfer surplus capital to their home countries.

\subsubsection{The theory of over population}

The growth of world population in relation to natural resources has cast doubt on the improvement of the welfare of mass majority of people. The prospects of international and domestic development are inhibited by the rapid population growth. The present increase in population and the rapidly decreasing food supply posed serious problems to the inhabitants of the world. There exist a dynamic relationship between population and development. The modernization school of thought has used the overpopulation argument to explain or attempt to justify the underdevelopment of backward countries. The contention is that, development is inhibited by rapid population growth and density in relation to natural resources and the rapid growth is a major feature of poor economies which accounts for their underdevelopment. To this theory, high population growth give rise to high supply of labour which in turn leads to high unemployment and this high unemployment leads to low productivity and low productivity give rise to low income and this traces its way back to the high fertility rate of this economies.

\subsubsection{Critique of Overpopulation theory}

The theory has been criticized on the grounds that it did not address the real causes of underdevelopment in the poor nations and that underdevelopment in these economies cannot be taken as natural. Also, it is not true that high fertility rate is a unique feature of poor nations but the present developed nations at their early stage of development also experienced rapid population growth. Similarly, there is no proper survey to confirm that the less developed countries are overpopulated. Some developing countries are fairly sparsely and densely populated. So to generalize that the less developed countries are overpopulated is to assume that they all have equal resource endowment. More so, what is evidently true of the less developed countries 
is that their resources are mismanaged and underutilized. So the need to check population growth as indicated by Malthus and Ricardo is necessary. The problem of starvation, low standard of living, unemployment calls for proper population planning. However, the importance of optimum population to development is noted to avoid misallocation of investment resources.

\subsubsection{PieroGheddo's four revolution theory}

PieroGheddo though a priest joined other western scholars to adduce reasons why some countries are developed and others underdeveloped. In his book "Why is the $3^{\text {rd }}$ world poor?" he explained the phenomenon of development and underdevelopment. A crucial question raised by this theorist in his work is that why have some people started to move forward while others remain motionless or static. The answer to this question was summarized in what he called four revolutions and these four revolutions are referred to as Gheddo's 4 revolutions. These revolutions he argued have taken place in the West while Third World countries were yet to undergo these revolutions and this is responsible for their underdevelopment. The four revolutions are:

a. The plain of idea: The argument of this revolutionary idea is that men are equal and their dignity is also equal among individuals in the society. He asserted that the Bible revealed this and maintained that man was the king of creatures and superior to all other creatures. That the West was able to attain structural transformation because of Judaism and Christian religion. However according to Gheddo the less developed countries are still ignorant and unaware of this idea and have not accepted the idea of man as the centre of creation. It is believed that these economies see man as any other creature without any special trait or attributes. He asserted that man cannot progress but remain in a close society and static in what he called the reoccurring circle of nature.

b. The idea of progress: The contention here is that since man is superior to all creatures; therefore, man ought not only to dominate nature but make nature to meet and serve his numerous needs. According to him, the West developed rapidly because of the discovery at a time the sovereign dignity of man over other creatures. According to Gheddo, the less developed countries are static because they lack what he referred to as progressive mentality which characterized the western man. He further argued that the underdevelopment of these economies are found in the nonChristian societies and pre-Christian societies who return to their past and remain closed.

c. Population growth: Population increase in the West, it is argued, took place in circumstance conducive to effort; hence organized in a manner to improve productive potentials leading to rapid economic development. However, Gheddo argued that in the less developed countries men are not aware of their equality and dignity. Increase in population has not led to increase in productivity and attainment of social justice.

d. Science and technology: Here, the revolution concerns itself with the development of science and technology in developed countries which has led to rapid development and science and technology is derived from the plain of ideas. That science and technology are planned efforts to enhance development. Commitment to achieve this strive is a manifestation of prolong planning. He argued further that to transplant science and technology in the less developed countries is not likely to succeed because of what he called cultural differences. In other words, cultural differences inhibit progressive ideas. To him, the less developed countries are not prepared and responsive to the eventual change in their cultural past as those in developed countries have undergone. In other words, science and technology play an important role in the advancement of the advanced countries which led to the existence of new class known as the bourgeoisie class that introduced progressive spirit which is lacking in the less developed countries. 


\subsubsection{Critique of Gheddo's four revolutions}

Gheddo has been criticized on the grounds that it is not true that Africans in particular and other less developed countries in general lack dynamic progressive social class; rather, intimidation from both within and outside have helped in no small way in causing the underdevelopment of the backward countries. Gheddo's analysis did not address itself to the main issues of underdevelopment of the less developed countries. The issues include colonialism, imperialism and neo-colonialism which were imposed by the activities of international economies. Secondly, it is also not true that Africans are still dogmatic and traditional and so engulf in a web of rigid socio-cultural pattern that inhibits progress. At any level of development for all colonies and even the advance countries experienced one form of traditionalism or the other. It is equally not true that all nations have to pass through the path followed by the west. Many countries like Japan for example is not a Christian society and yet had witness a lot of progress.

In general while modernization theory understood development and underdevelopment as a result from internal conditions that differ between economies, dependency theory understood development as rational. It saw the world's nations as divided into a core of wealthy nations which dominate a periphery of poor whose main function in the system is to provide cheap labour and raw materials to the core. Also, modernization theory failed to explain some critical issues patterning the underdeveloped nations such as demographic trends, difference in culture, geographical position, etc.

In sum, the criticisms of various modernization theories came primarily from dependency theory and underdevelopment theorists. The main critical points were:

a. Modernization theory concentrated on internal social processes, thus ignoring the effects of colonialism and neocolonialism on the structure of $3^{\text {rd }}$ world societies;

b. The contrast between modern and traditional was both oversimplified and erroneous. Frank argued that existing $3^{\text {rd }}$ world societies were not in any sense because they had been changed by centuries of contact with Northern countries. The obstacles to change were a creation of this contact;

c. These were not dual societies because often the so-called traditional sector were an integral part of the national economy;

d. The evolutionary approach imposed a western model of development and denied the possibility of novel forms of society emerging in the $3^{\text {rd }}$ world;

e. Behind modernization theory were both political and ideological concerns.

\subsection{Dependency theory}

Dependency theory is a body of social science theories predicated on the notion that resources flow from a "periphery" of poor and underdeveloped states to a "core" of wealthy states, enriching the latter at the expense of the former (Wikipedia, free encyclopedia). It is a central contention of dependency theory that poor states are impoverished and rich ones enriched by the way poor states are integrated into the "world system".

Dependency theory was first developed by economists in Latin America in the 1950s in opposition to the prevailing orthodoxy that $3^{\text {rd }}$ world countries could achieve modernization and industrialization by following the examples of the already industrialized world (Jary and Jary 2000:148).

The theory arose around 1960s or 1970s as a reaction to earlier theories of development which held that all societies progress through similar stages of development, that today's underdeveloped areas are thus in a similar situation to that of today's developed areas at some time in the past, and that therefore the task in helping the underdeveloped areas out of poverty is to accelerate them along this supposed common path of development, by various means such as investment, technology transfers and closer integration into the world market. Dependency theory rejected this view, arguing that underdeveloped countries are not merely primitive versions of developed countries, but have unique features and structures of their own; and 
importantly, are in the situation of being the weaker members in a world market economy, whereas the developed nations were never in analogous position; they never had to exist in relation to a bloc of more powerful countries than them (Wikipedia, free encyclopedia). Dependency theorists argued, in opposition to free market economists. The theory opined that the underdeveloped countries needed to reduce their connectedness with the world market so that they can pursue a path more in keeping with their own needs, less dictated by external pressures.

Dependency theory was developed from a Marxian perspective by Paul A. Baran in 1957 with the publication of his The Political Economy of Growth (Vernengo, 2004).Baran's work inspires Marxist Dependency and World systems theories. Dependency theory was embraced by many Marxists and neoMarxists. Neo-Marxists insisted that what was called 'development' was really a process of capitalist development: the global expansion of the capitalist mode of production at the expense of pre-capitalist ones. And the outcome of such a process might not be 'real development' in a sense of better life for people in the Third World at all. The dependency theorists held that for underdeveloped nations to develop, they must break ties with developed nations and pursue internal development growth strategy. According to the neoMarxists scholars and in particular Andre Gunder Frank and Samir Amin's analysis of the development of the Third World countries, they maintain that the relationship between the center i.e. capitalist West and the periphery i.e. Third World countries has remained exploitative. According to them the exploitation is in terms of surplus transfer of capital, goods and raw materials from the periphery to the center, which has perpetuated or maintains the underdevelopment of periphery. The West has been able to maintain its domination and exploitation over the Third world countries through the process of colonialism and imperialism. In other words, the demand for raw materials, cheap labor, goods and services by the European economies gave rise to their desire to control the human and material resources of the Third world.

Another general aspect of the Third world which is an internal problem is their lack of enterprenual and administrative talent necessary to initiate developmental policies, programmes and projects and that only the state apparatus is capable of initiating this. Even then, its ruling class is also dependent on western experts who are their Godfathers. Samir Amin particularly rejected the idea that in all societies there is a kind of dualism whereby some sections are rich while some remain poor. To him and his colleagues, they belief that there is compulsive and direct interference in the transfer of surplus values i.e. wealth and capital from rural areas within the less developed countries to their urban areas and finally from these less developed countries' periphery to the center (advanced capitalist countries).

Andre Gunder Frank on the other hand contributed to the theory of underdevelopment by studying Latin American countries. According to him, for one to understand underdevelopment in some countries, one must look into their past; economic, social and political structure. He maintains that, in Latin American countries, underdevelopment is as a result of their long centuries' participation in the expansion and development of the capitalist system. He argues that, the conquest of Chile and other Latin American countries not only incorporated them into the global capitalist network, but it introduced into these countries, monopolistic, metropolis-satellite structure. It also introduced into these countries, development of capitalist economic system. According to Frank, colonialism introduced into countries like Brazil, export economy which resulted into the development of satellite pattern of relationship. He maintains that capitalist expansion in the underdeveloped region brings about satellite development which was neither self generating nor perpetrating. This means that the system does not allow Third world nations' economy to have forward and backward linkages; it does not allow the economy to control itself rather, controlled by outsiders. For example, oil is a natural resource found in the Third world nations but the Third world nations will wait for the developed countries to use their technology to process these resources for them. In addition, Frank believes that, the most underdeveloped regions or countries in the continent of Latin America were those that closet ties with the metropolitan countries. As such the underdeveloped countries became the source of production of primary products as well as the major source of surplus capital for developed countries. He therefore argued that when the resources of the underdeveloped countries disappeared, the metropolitan countries will 
abandoned them, and that will be responsible for underdevelopment in those countries.

On a final note, Frank believes that, the expansion and development of capitalism is responsible for the imbalance allocation of resources among the continents of the world. With these developments, the advanced capitalist countries expropriated the surplus capital of Third world nations for their development. Therefore, the satellite countries remained underdeveloped mainly because of lack of access to their own surplus capital. Frank further argued that, the underdevelopment of the Third world nations is not as a result of archaic institutions and capital structures, but it is generated by the same historical process that isolated the Third world nations from the mainstream of history. On the contrary, underdevelopment is generated by the same process of development in some parts of the world.

\subsubsection{A critique of the Dependency theory}

Dependency theory was very influential in sociology in the 1970s. Whilst often termed neo-Marxist, it came under increasing criticism from Marxist writers. In particular, it has been criticized for concentrating on market rather than production relations. In one of the rigorous critiques, Taylor (1979) has argued that the central concept of economic surplus is extremely weak. More general criticisms include its relative neglect of the contribution of internal social relations to problems which poor countries face, and the increasing diversity of their experiences (Jary and Jary 2000:149).

The dependency theorists tend to blame outside forces for the underdevelopment of the Third world nations and other social problems within the continent. Ethiopia for example had relatively short contact with the Europeans, yet, it is one of the most underdeveloped nations in the world. The dependency theorists further argued that the Third world nations should break away for them to develop on their own but this assertion has not taken into consideration that there are indigenous exploiters who siphon the societal wealth to the various banks in advanced countries. Similarly, they ignored internal factors contributing to the underdevelopment of Third World countries. The factors are as follows:

i. Problems of politics and planning: For any development objective to succeed, there must be conscious and committed attempt on the part of the people and government in pursuing such objective. Planning problems in the Third world countries are as a result of lack of commitment and political will of the governments of these countries. This lack of commitment stems from greed and corruption which are also endemic characteristics of the Third world societies. Deliberate poor or unserious planning for development in Third world countries is because of the magnitude of corrupt practices.

ii. Low level of living and poverty: This involves low nutrition, poor shelter and clothing and general inadequacy of basic conditions of living and non availability of basic needs of life. The low per capital income is reflected in low living standard of the people. About $75 \%$ of the income is spent on food compared to $20 \%$ in advanced countries. Most of the people in the $3^{\text {rd }}$ world take starchy food to the total absence nutritional food such as eggs, fish, meat and dairy products. There is also a high rate of infant mortality due to poor nutrition, unsafe water, poor sanitation etc. Other forms of poverty include poor health and education.

iii. High rate of unemployment: One of the core values of development which is employment opportunities is grossly inadequate in Third World countries. These countries are characterized by high rate of unemployment. Only light industrialization is visible; therefore, the sole employer of labour is government and government cannot certainly provide enough employment opportunities. The agricultural sector which is supposed to provide self employment to people has been neglected by some of the Third world countries. In Nigeria for example, agriculture has been neglected; the country now rely on oil at the expense of the development of Agro-Allied activities for capital generation and the creation of employment opportunities.

It is obvious from the above that factors that led to the underdevelopment of the Third world countries 
are both external an internal. Therefore, to deal with the problems of the Third world countries-Nigeria in particular concerted efforts have to be put in place to tackle both the internal and external factors.

Both Modernization and Dependency theories did not looked at the peculiarity of development problems in Africa. The two theories cannot stand as development concepts for all third world countries.

The supporters of modernization theories assumed that a linear process exists whereby developing countries progressively become industrialized. As said above the reason for the underdevelopment of countries were seen within the different the societies in internal factors, for example, in their tradition or in the lack of sufficient capital investment.

Theories around dependency were based on the assumption that the historical process of the spread of capitalism resulted in the underdevelopment of the periphery, which are called the Third World. External factors like colonialism, the capitalist world economy and world market integration were considered responsible for the lag in the periphery's development.

The two theories have been criticized on the following grounds:

i. Difference within the $3^{\text {rd }}$ world: The success within the "Asian tigers" has been the most recent example that theoretical assumptions have been wrong. These theorists had to take into account that major differences existed, for example, between the Asian tiger states, the annuity capital oil countries and the agrarian societies of Africa. Some authors doubt that Third World ever existed: "it is only a product of our roughly hewn analytical categories" (Boeckh, 1993:111).

ii. Problems inherent in the theories: The main argument made against the grand theories is that they raise their heuristic concepts to the level of universal theories of reality.

Another common critique maintains that these theories are one-dimensional: Modernization theories reduce the reasons for underdevelopment to internal, the dependency to external factors.

iii. Consequences of the global theories: The modernization and dependency theories did not fail completely; they only fail to live up to their own goal. They cannot stand as development concepts for all $3^{\text {rd }}$ world countries, but they can serve as an analytical framework for future research. Predictions regarding the probability of development, stagnation or underdevelopment require a comparative typology of path of development that has yet to be written. Categories and concepts from grand theories that name the internal and external conditions of development could then lie useful.

In line of the weaknesses of modernization and dependency theories, current thinking has moved away from global explanations, with the exception of neoliberlalist paradigms.

\subsection{World Systems Theory}

World system according to Collins internet linked dictionary of sociology, is " a conception of modern social world which views it as comprising one interlinked entity with an international division of labour unregulated by any one political structure" (p.685).

World systems theory develops in response to some of the criticisms of dependency theory. The division of periphery and center was further divided into trimodal system consisting of the core, semiperiphery and periphery. In this system, the semi-periphery lies between the core and periphery and is exploited by the core and exploits the periphery. World system theory was initiated by Immanuel Wallerstain in, among other writings, world systems analysis, and focuses on inequality as a separate entity from growth in development and examines change in the global capitalist system. One distinguishing feature of the theory is distrust for the state and a view in which the state is seen as a group of elites and that industrialization cannot be equated with development (Wikipedia, free encyclopedia) . 


\subsubsection{A Critique of World Systems Theory}

At an earlier stage world system theory has been criticized for overemphasizing the world market while neglecting forces of production. According to Wallerstain himself, critique of the world system comes from four directions: from the positivists, the orthodox Marxists, and the culturalists. The positivists criticized the approach as too prone to generalization, lacking quantitative data and failing to put forth a falsifiable proposition. The orthodox Marxists find the world system too deviating from orthodox Marxists principles, such as not giving enough weight to the concept of social class. The autonomists criticized the theory for blurring the boundaries between states and business. Further, the positivists, the orthodox Marxists and the autonomists argue that the state should be the central unit of analysis. Finally, the culturalists argue that the world system theory puts too much importance on the economy and not enough on the culture (Wikipedia, free encyclopedia).

\section{Concluding Remarks}

It is obvious from the foregoing discussion that none of the development theories is devoid of criticisms and more so none originated from Nigeria in particular or Africa as a whole to deal with the developmental intricacies of the country or the region. However, some of the assumptions of the theories could be used in an attempt to explain the developmental problems of Nigeria in particular and Africa in general. For example, Alanana (2010) argued that development and social order have not been genuinely achieved in Nigeria because of her over dependence on Europe during the historical periods of slavery, colonialism and neocolonialism. Forced migration under slavery denied the country the opportunity of advancing further technologically, and politically. He further argued that: "under colonialism, Nigeria was conquered and aggressively incorporated into the global capitalist system... domestic production was oriented away from domestic needs to metropolitan needs of the world imperialist system".

Apart from orienting production towards the metropolitan needs, monopoly agencies such as the marketing boards, among others were established and assigned the responsibility of fixing prices for agricultural produce such as cocoa, rubber, palm oil, groundnut in favour of Britain and her allies (Ake, 1989). These arguments are in line with the major assumptions of the dependency theories.

In addition to dependency theory, Seers' argument is thus relevant in an attempt to explain development in Nigeria. As stated earlier, Seers said that there are three fundamental questions to be asked about the development of a country. These are what happened to poverty, what happened to unemployment, what happened to inequality? He argued that if these variables are on the decline from high level, then beyond doubt there has been a period of development of the country concerned. But if one or two of these central indicators are going worse, it will be strange to call the result development even if the national income has developed like in the case of Nigeria. In terms of development in Nigeria there is nothing to write home about as the nation is bedeviled with high level of poverty as a result of unemployment and inequality.

In summary the paper adopted the major assumptions of the dependency theories and Dudley Seers' indices for measuring development.

\section{References}

Ake, C. (1989). The Political Economy of Africa.Ibadan; Longman.

Alanama, O.O (2010). " Understanding Development and Social Order in Nigeria: A theoretical Approach", A paper presented at the $15^{\text {th }}$ Annual Conference of Nigerian Anthropological and Sociological Association (NASA) Held at Ahmadu Bello University, Zaria, April $16^{\text {th }}-18^{\text {th }} 2010$.

Amzat, J. (2009). "Assessing the progress towards the Millennium Development Goals in Nigeria', In State and Civil Relations in Nigeria, Hope Publication Ltd., Ibadan, Nigeria.

Baran, P.A (1957). The Political Economy of Growth. New York monthly Review Press. 
Dansabo, M.T (2006) "Nigerian Social Structure and Development: A Sociological Anatomy of Social Problems" In The Social Costs of Privatization and deregulation in Nigeria, NISS Publication, Ikeja-Lagos.

Foster, J.B (2011). The Imperialist World system: Paul Baran's Political Economy of Growth after fifty years.

Jary, J. (2000). Collins Internet Dictionary of Sociology. Happer Collins publishers, Glasgow-Great Britain.

Mohammed, I.Z (n.d). "A Discourse on the relationship between Social problems, Poverty, inequality and unemployment in Nigeria, Department of Sociology, Bayero University, Kano.

Pitt, D.C (1976). The Social Dynamics of Development.Pergamon press, Oxford.

Rodney, Walter (1972). How Europe Underdeveloped Africa.London L' Duverture Publication.

Seers Dudley (1973), "The Meaning of Development" In Political Economy of Development (eds) Uphoff and W.R. Hehman, University of California Press.

Vernengo, M. (2004) "Technology, Finance and Dependency: Latin American Radical Political Economy in Retrospect", University of Utah, Department of Economics.

Wikipedia, Free Encyclopedia. 
